\title{
MEDIA LITERACY IN EXTRACURRICULAR ACTIVITIES
}

\author{
Katarina Vanek \\ University of Zagreb, Croatia
}

\begin{abstract}
This research has been set in view of the increasing exposure of children and youth to the media and the challenges of the modern education system. The aim was to establish the existence and representation of extracurricular activities in school curricula aimed at media literacy of students in primary schools in the area of Virovitica-Podravina and PožegaSlavonia Counties in the Republic of Croatia. The data were collected by studying the documentation - analysis of 25 school curricula for the 2020/2021 school year, which are available on websites of the schools. The results are described by the descriptive method and point to the existence of extracurricular activities aimed at media literacy of students, but not in all schools. Such extracurricular activities are more represented in higher grades of primary school ( $5^{\text {th }}-8^{\text {th }}$ grade) and are mostly oriented toward journalism, while in lower grades $\left(1^{\text {st }}\right.$ $4^{\text {th }}$ grade) the most frequent activities are related to Computer Science or a specific aim set within media literacy education. Finally, this research can be a starting point for other research projects for determining the causal links that led to such results and an incentive to improve educational practice in Croatian schools.
\end{abstract}

Keywords: extracurricular activities, media literacy, school curriculum.

\section{Introduction}

Technological development has created new media that are available to children, every day and throughout the entire day, especially in urban environments. This is the reason why children increasingly learn informally through various media which, as message transmitters, must not be omitted in the formal education system. It is extremely important to educate children and young people about the media, their content and how to use them safely while offering critical reflection on the content and teaching them how to use the information they can find in the media.

In the context of communication sciences, medium (from Latin medium: middle, means) is a means that mediates the transmission of messages, notices, news, etc. Electronic means, newspapers, the Internet, film, etc. are considered the media. Due to their availability to the wider population, they are called the mass media and can be categorised as print, book, radio, film, television, image, and sound media. Traditional media are connected with computer technology, 
thus creating interactive media and making the term communication media increasingly used. Zgrabljić Rotar (2017) divides the newly created media environment into three groups: traditional, converged, and new media. The above division shows changes in the media brought about by digitalisation resulting in the relocation of traditional media content to new platforms leading to numerous multimedia formats (Syvertsen, Enli, Mjøs, \& Moe, 2014).

Media literacy was defined in 1992, at the National Leadership Conference on Media Literacy, as "the ability to access, analyse, evaluate and transmit messages via the media” (Aufderheide, 1992 as cited in Zgrabljić Rotar, 2005). Similarly, Livingstone (2003) defines media literacy as "the ability to access, analyse, evaluate and create messages across a variety of contexts". Livingstone and Thumim (2003) highlight that access to media devices is a prerequisite for developing media literacy skills and introduce three stages of media literacy: technical competencies, critical reception practices, and content production. Moreover, Burn and Durran (2007) give a summarized definition of media literacy by describing it as a subset of multiliteracy which is in particular applicable to mass media.

\section{The Importance of Media Literacy in Schools}

Friesem, Quaglia Beltran and Crane (2014) state that concerns about media influence started back in the 1960s, but the problem has remained unsolvable even today. In order to overcome this problem, contemporary curricula should ensure knowledge, skills, and competences required by modern man. That is the reason why media education should be an important component of the contemporary education curricula which, according to Previšić (2005), includes "scientific establishment of goals, tasks, content, planning, organisation, and technology of implementation, and various forms of evaluation of effects”. Pavičić Vukičević (2019) underlines the continuous need to revise and innovate the curriculum in order to respond to the challenges it faces and the needs of contemporary society, which is why Matijević and Rajić (2015) state that the starting point for every curriculum planning and design should be a modern child belonging to the Internet generation.

The need to put the Internet generation at the centre of attention in curriculum drafting is confirmed by the research results in the USA showing that an average child spends 50 hours a week watching television or interacting with the electronic media (Hattie \& Yates, 2014). It is therefore important to bear in mind that students today process information differently from their ancestors (Marc Prensky, 2001 as cited in Hattie \& Yates, 2014). Furthermore, more than $35 \%$ of 300 media education experts in the conducted survey highlight the most important aims in teaching media literacy in school: demonstrate an 
understanding of the types of media texts and the role of media in democratic societies, recognize the types of media, create media text for self-expression intended for different audiences using appropriate media language, and analyse and critically evaluate media representations of people, subjects, values and behaviour (Fedorov, Levitskaya, \& Camarero, 2016). Vrkić Dimić (2014) emphasizes the importance of critical evaluation by claiming that it has become more important than ever so that it reduces the individual's ability to only imitate others and enables him to be innovative.

\section{Media Literacy in Croatian Education System}

The concept of media literacy was first mentioned in Croatia in 2014 in the document called The Strategy for Education, Science and Technology, stating that media literacy was represented in various degrees within the subject of the Croatian language in its portion on media culture and Computer Science in primary school. There were also many projects within a homeroom class, extracurricular activities, library activities, and various activities in film or journalism clubs. It was also pointed out that children and young people in Croatia in the existing educational system have a partial access to media education in general (Kanižaj \& Car, 2015). Although new media (mobile devices, the Internet, etc.) have a prominent place in education, they are still quite omitted in curricula. According to the Study on Assessment Criteria for Media Literacy Levels, the purpose of media education should be to stimulate individuals to access all kinds of media in the form of tools for understanding the world and participating in the community because critical thinking and active citizenship depend on the development of media literacy (EAVI, 2009).

Media education is represented in The National Curriculum Framework for Pre-School Education and General Compulsory and Secondary Education (MZOŠ, 2011) which Baranović et al. (2015) presents as the basis for continuing education and assessing professional orientation, with the state determining the level and direction of human capital, while Mlinarević and Zrilić (2015) define it as a development document that is the starting point and the basis for all other documents. That is why the focus on media education is extremely important in the national framework curriculum. In the National Framework Curriculum, media education was highlighted in the cross-curricular theme "Use of ICT", Computer Science subject and in the language and communication section which states the need for media culture and development of the critical approach to media content (MZOŠ, 2011). The most important part of media education is envisaged within the curriculum of Croatian Language - Culture and Media, which follows the Council Recommendation on Key Competences for Lifelong 
Learning stressing the importance of improving media literacy (European Commission, 2018).

\section{Media Literacy in Extracurricular Activities}

One of the important ways of improving media education in Croatia is school curricula. The National Framework Curriculum is a foundation for the development of school curriculum (Sučević, Sakač, \& Bulatović, 2013) which Jurić (2005) describes as the basic document of school which envisages the working of a school institution, the way it operates and ultimately evaluates the effects of school on students and teachers. The aim is to stimulate the development of skills and abilities that enable students to overcome everyday life challenges (Buljubašić Kuzmanović \& Blažević, 2015), which are reflected in projects, elective courses, and extracurricular activities in accordance with school equipment and needs of the local community whose educational goals can be carriers of media literacy of students of a particular school. Miliša and Ćurko (2010) stress the need to implement media education in order to form instructions and methodology proposals for teaching children critical thinking when it comes to the information they receive through the media.

Extracurricular activities are prescribed by law and are a part of the culture of Croatian schools. Each school has the freedom to choose and implement different extracurricular activities (Svalina, Bistrović, \& Peko, 2016) which gives each school the opportunity to organise extracurricular activities aimed at media education. Students engage in extracurricular activities according to their own interests, and by participating in them, they achieve desirable goals arising from those interests and needs. In this way, children fulfil their free time in a quality way (Svalina, Bistrović, \& Peko, 2016).

Considering the increasing exposure of children and youth to different media content, and thus the growing need for media literacy, this research aimed to establish the existence and representation of extracurricular activities in school curricula aimed at media literacy of students in primary schools in the ViroviticaPodravina and Požega-Slavonia Counties in the Republic of Croatia. In accordance with the aim, the following research questions were raised:

- Are there extracurricular activities in school curricula aimed at the media literacy of students?

- What are these extracurricular activities aimed at the media literacy of students?

- Which extracurricular activities aimed at media literacy of students are most represented in lower (1-4) grades and which in higher (5-8) grades of primary school? 
- What is the representation of extracurricular activities aimed at media literacy of students in relation to the total number of extracurricular activities in schools?

The method of data collection was working on documentation - the analysis of 25 school curricula for the 2020/2021 school year available on websites of primary schools. The results are described by a descriptive method.

\section{Methodology}

The non-probability intentional sampling of this non-empirical research consists of the curricula of 25 primary schools for the 2020/2021 school year in two selected counties in Croatia. The school curricula were obtained on the websites of 13 primary schools from Virovitica-Podravina County and on the websites of 12 primary schools in Požega-Slavonia County. The list of primary schools in these counties was obtained on the web portal for schools in Croatia skole.h. The method of data collection was working on the documentation. The instrument of data collection from school curricula was a record sheet. The analysed extracurricular activities in school curricula were all those containing clearly stated goals and ways of realization, as well as stated grades for which these activities are intended all with the purpose of finding answers to the posed research questions. Only extracurricular activities aimed at media literacy of students were singled out. A quantitative content analysis was used in this research and the results were described by the descriptive method.

\section{Research Results and Discussion}

The results of the analysis of the primary school curricula point to the existence of extracurricular activities aimed at media literacy of primary school students (Table 1). Out of 25 schools, there are 2 schools that do not have any such activities and there are as many as 9 schools that have only one such activity. These results indicate a lack of media literacy representation in the extracurricular activities of primary schools although schools have freedom to choose extracurricular activities to implement in their curricula (Svalina, Bistrović, \& Peko, 2016). Given the constant exposure of children and young people to different media content and devices through which they access them, schools should have extracurricular activities that teach students the skills necessary to safely and purposefully use and create media content. 
Table 1 Number of Extracurricular Activities Aimed at Media Literacy in Schools

\begin{tabular}{|c|c|c|c|}
\hline SCHOOL & $\begin{array}{c}\text { NUMBER OF } \\
\text { ACTIVITIES }\end{array}$ & SCHOOL & $\begin{array}{c}\text { NUMBER OF } \\
\text { ACTIVITIES }\end{array}$ \\
\hline No.1 & 5 & No.14 & 1 \\
\hline No.2 & 6 & No.15 & 1 \\
\hline No.3 & 6 & No.16 & 2 \\
\hline No.4 & 3 & No.17 & 1 \\
\hline No.5 & 0 & No.18 & 2 \\
\hline No.6 & 1 & No.19 & 1 \\
\hline No.7 & 1 & No.20 & 2 \\
\hline No.8 & 4 & No.21 & 4 \\
\hline No.9 & 1 & No.22 & 3 \\
\hline No.10 & 2 & No.23 & 1 \\
\hline No.11 & 2 & No.24 & 1 \\
\hline No.12 & 0 & No.25 & 2 \\
\hline No.13 & 2 & \multicolumn{2}{|l}{} \\
\cline { 1 - 3 } & &
\end{tabular}

Extracurricular activities that appear in at least two schools are visible, while activities that appear in individual schools are omitted (Table 2). The most prevalent extracurricular activity in 12 schools is focused on journalism. This activity appears in 12 schools only from $5^{\text {th }}$ to $8^{\text {th }}$ grade and never from $1^{\text {st }}$ to $4^{\text {th }}$ grade (Table 2). News and reading literacy is a part of media education which is much represented in Croatia. It provides knowledge about creating news, aspects of journalism etc. (Petranová, Hossová, \& Velický, 2017). That may be the reason why there are so many extracurricular activities focused on journalism in the analysed school curricula.

According to the goals stated by schools for journalistic extracurricular activities, students acquire numerous competencies in creating media content for the printed media - newspapers. Those activities include an introduction to basic concepts, analysis and critical overview of media content, field research such as conducting interviews, creating media content in the form of photographs and written texts, publishing their own newspaper articles in the school newspaper and on the school website. Due to the location of publication of these articles, this extracurricular activity can also be associated with the activity that points to the creation of a school newspaper in two schools and activity that points to online journalism in three schools. By linking these three extracurricular activities, there is even more to the point that among all schools, the most represented extracurricular activities are closely related to journalism so there are 17 of them accounting for $68 \%$ of all schools whose curricula were analysed in this research. We can see a great link between the traditional printed media - newspapers and digital media. Students in such extracurricular activities can understand the unbreakable link between traditional and new media because all the media they 
encounter in the press are previously created in a digital form. At the same time, it is important that students perceive the possibility of distorting information in certain media texts or rearranging photographs that have been published, which ultimately leads them to understand the importance of a critical overview of the media surrounding them every day and the social responsibility they have as creators of media content. Improving the ability of a critical overview of the media content may lead to improving individual's ability to be innovative (Vrkić Dimić, 2014).

Table 2 List of Extracurricular Activities Aimed at Media Literacy of Students

\begin{tabular}{|c|c|c|c|}
\hline \multirow{2}{*}{$\begin{array}{c}\text { EXTRACURRICULAR } \\
\text { ACTIVITY }\end{array}$} & \multirow{2}{*}{$\begin{array}{c}\text { NUMBER OF } \\
\text { SCHOOLS }\end{array}$} & \multicolumn{2}{|c|}{$\begin{array}{c}\text { NUMBER OF } \\
\text { ACTIVITIES }\end{array}$} \\
\cline { 3 - 4 } & & GRADE 1-4 & GRADE 5-8 \\
\hline Multimedia & 2 & 1 & 1 \\
\hline Journalism Club & 12 & 0 & 12 \\
\hline $\begin{array}{c}\text { School Newspaper - publishing } \\
\text { activity }\end{array}$ & 2 & 2 & 2 \\
\hline Website - Online Journalism & 3 & 1 & 3 \\
\hline Literary Club & 3 & 1 & 3 \\
\hline Photo and Video & 6 & 2 & 4 \\
\hline Computer Science & 6 & 3 & 3 \\
\hline Media Literacy & 6 & 3 & 5 \\
\hline Literary Journalism Club & 3 & 0 & 3 \\
\hline Film and Cinema & 3 & 0 & 3 \\
\hline
\end{tabular}

Regarding the extracurricular activities aimed at media literacy, Table 2 shows that there is a significant difference between lower and higher grades of primary school. In lower grades, the most prevalent activities are related to Computer Science and media literacy. The objectives listed in the curricula for activities related to Computer Science are mainly aimed at developing digital and Computer Science competences, which are important segments of media literacy and without which it is impossible to be "media literate" because knowledge on the use of certain digital devices is essential for accessing media content that provides us with different information. Furthermore, such activities are aimed at acquiring different ICT skills in the form of independent content creation, work, and communication in an online environment, etc. Besides, the second most represented activity in lower grades is media literacy which points to a wide range of competences and skills included in media literacy: grasping of basic concepts, critical view of media messages and their understanding within the social and cultural environment, creating media messages, developing awareness about the importance of understanding the scope of media literacy, safe use of the Internet 
and ways of collecting information and their formation into media content closely related to journalism. Such extracurricular activities should provide the most complete media education in which students will acquire skills for a proper approach to different media content, analysis and critical overview of media content, and ultimately the independent and responsible creation of media content.

The results in Table 2 point to a lack of journalistic extracurricular activity in lower grades, indicating that students of younger school age are not considered competent enough for the challenges of journalistic activities. Journalistic extracurricular activities introduced from an early age might have a positive effect on students by providing citizenship education which is very important in the era of globalisation in which we live (Wahyuningsih, Roesminingsih, \& Setyowati, 2018). However, activities related to the creation of a school newspaper and participation in the creation of content on the school website are represented in lower grades, which is confusing if we question why students of younger schoolage can become involved in creating a school newspaper or website content, but cannot be included in exclusively journalism clubs. This situation raises some questions: Why are journalism clubs focused on higher grades students? Do students of younger school-age actively participate in the creation of school newspaper and website content or are they mostly just passive observers?

The share of extracurricular activities aimed at media literacy in the curricula of all analysed schools is $8.00 \%$ although children and youth are very exposed to the media. The results indicate that such extracurricular activities are $3.76 \%$ more represented in higher grades than in lower grades, which reflects less exposure of younger primary school students to activities liked to media literacy (Table 3). Also, media literacy is in some other countries directed just to higher grades of primary and secondary schools such as Hungary and Austria (Zhang, Zhang, \& Wang, 2020) or in even higher level of education such as in Bulgaria, Spain and Slovakia (Petranová, Hossová, \& Velický, 2017). But, media specialists are focused on incorporating media education in school curriculum even for lower levels of education (Petranová, Hossová, \& Velický, 2017).

Table 3 Share of Extracurricular Activities Encouraging Media Literacy of Students in Relation to the Total number of Extracurricular Activities

\begin{tabular}{|c|c|c|c|}
\hline & $\begin{array}{c}\text { All } \\
\text { activities }\end{array}$ & $\begin{array}{c}\text { Activities aimed at } \\
\text { media literacy }\end{array}$ & $\begin{array}{c}\text { Share in the total } \\
\text { number of } \\
\text { extracurricular } \\
\text { activities }\end{array}$ \\
\hline $\begin{array}{c}\text { Lower grades } \\
\left(1^{\text {st }}-4^{\text {th }}\right)\end{array}$ & 306 & 18 & $\mathbf{5 . 8 8} \%$ \\
\hline $\begin{array}{c}\text { High grades } \\
\left(5^{\text {th }}-8^{\text {th }}\right)\end{array}$ & 394 & 38 & $\mathbf{9 . 6 4} \%$ \\
\hline TOTAL & 700 & 56 & $\mathbf{8 . 0 0} \%$ \\
\hline
\end{tabular}


The presented results of this research make a scientific and practical contribution. The scientific contribution is reflected in numerous uninvestigated causal links that can explain these results and then explore the possibilities of making progress in the media literacy of students in Croatia. Furthermore, the practical contribution is reflected in teachers' awareness on the lack of extracurricular activities aimed at media literacy of students, which encourages teachers to engage further towards better education of Internet generations.

Finally, it is important to emphasize the limitations of this research. The conducted research included only 25 schools from two counties and their curricula that were available on the school websites and that met all the requirements for the analysis in order to answer research questions and achieve the research goal. In order to obtain a more accurate overview, such research should be conducted at the national level.

\section{Conclusions}

Media literacy is a basis for an active citizenship and critical thinking (EAVI, 2009) which may be an initial point for improvement of individual's ability to be innovative (Vrkić Dimić, 2014). Therefore, it is important to implement media literacy into school curriculum. A way to do it may be designing specialized extracurricular activities aimed to encourage students' media literacy. 25 analysed primary school curricula in this research show that there are extracurricular activities aimed at media literacy of students in primary schools in ViroviticaPodravina and Požega-Slavonia Counties in Croatia, but they are not equally represented in all schools. That contribute to partial access to media education in the Croatian educational system (Kanižaj \& Car, 2015). There are even schools that do not have any such extracurricular activity, which is inconsistent with the lifestyle of children and youth nowadays and shows that a starting point for planning and designing some school curricula is not a modern child (Matijević \& Rajić, 2015). Moreover, such extracurricular activities have a small share in the total number of extracurricular activities in primary schools and are more represented in higher grades with most activities directed at journalism, while in lower grades the most frequent activities are directed at the very concept of media literacy and are related to Computer Science.

Finally, the results clearly indicate the lack of media literacy of primary school students in offered extracurricular activities given the daily exposure of children and youth to the media. There is a wide range of possibilities in education for progress and further awareness of the importance of media literacy in life and the advancement of a modern man. 
Vanek, 2021. Media Literacy in Extracurricular Activities

\section{References}

Baranović, B., Domović, V., Matić, J., Puzić, S., \& Vizek Vidović, V. (2015). Školski kurikulum - teorijski i praktični apsekti. Zagreb: Institut za društvena istraživanja u Zagrebu.

Buljubašić Kuzmanović, V., \& Blažević, I. (2015). The school curriculum in the development of social skills of pupils. Pedagogijska istraživanja, 12(1-2), 85-85.

Burn, A., \& Durran, J. (2007). Media literacy in schools Practice, production and progression. London: Paul Chapman Publishing.

European Association for Viewers' Interests (EAVI). (2009). Study on Assessment Criteria for Media Literacy Levels. Retrieved from https://ec.europa.eu/assets/eac/culture/ library/studies/literacy-criteria-report_en.pdf

European Commission. (2018). Council recommendation on Key Competences for Lifelong Learning. Retrieved from https://eur-lex.europa.eu/legal-content/EN/TXT/?uri= CELEX:52018DC0024

Fedorov A., Levitskaya, A., \& Camarero, E. (2016). Curricula for Media Literacy Education According to International Experts. European Journal of Contemporary Education, 17(3), 324-334. DOI: doi:10.13187/ejced.2016.17.324

Friesem, Y., Quaglia Beltran, D., \& Crane, E. (2014). Media Now: A Historical Review of a Media Literacy Curriculum. Journal of Media Literacy Education, 6(2), 35-55. DOI: 10.23860/JMLE-2016-06-02-4

Hattie, J., \& Yates, G. (2014). Visible Learning and the Science of How We Learn. London, UK \& New York, NY: Routledge.

Jurić, V. (2005). Curriculum of contemporary school. Pedagogijska istraživanja, 2(2), 185-186.

Kanižaj, I., \& Car, V. (2015). Hrvatska: Nove prilike za sustavan pristup medijskoj pismenosti. In V. Car, L. Turčilo, \& M. Matović (Eds.), Medijska pismenost-preduvjet za odgovorne medije: zbornik radova s 5. regionalne znanstvene konferencije Vjerodostojnost medija (pp.23-41). Sarajevo: Fakultet političkih nauka.

Livingstone, S. (2003). The changing nature and uses of media literacy. Media@LSE Electronic Working Papers, No. 4.

Livingstone, S., \& Thumim, N. (2003). Assessing the media literacy of UK adults. Retrieved form https://core.ac.uk/download/pdf/94823.pdf

Matijević, M., \& Rajić, V. (2015). Metodologije kurikulumskih promjena: nekad i danas. In S. Opić, \& M. Matijević (Eds.), Istraživanja paradigmi djetinjstva, odgoja i obrazovanja, IV. simpozij: Nastava i škola za net-generacije: Unutarnja reforma nastave u osnovnoj $i$ srednjoj školi (pp.635-654). Zagreb: Učiteljski fakultet, Sveučilišta u Zagrebu.

Miliša, Z., \& Ćurko, B. (2010). Odgoj za kritičko mišljenje i medijska manipulacija. MediAnali, 4(7), 57-72.

Ministarstvo znanosti, obrazovanja i športa (MZOŠ). (2011). Nacionalni okvirni kurikulum za predškolski odgoj i obrazovanje te opće obvezno i srednjoškolsko obrazovanje. Retrieved from http://mzos.hr/datoteke/Nacionalni_okvirni_kurikulum.pdf

Mlinarević, V., \& Zrilić, S. (2015). Strateški, kurikularni i zakonski dokumenti kao temelj razvoja socijalnih kompetencija u hrvatskoj školi. Školski vjesnik, 64(2), 283-308.

Pavičić Vukičević, J. (2019). Suvremene kurikulumske polemike. Zbornik sveučilišta Libertas, 4(4), 203-218.

Petranová, D., Hossová, M., \& Velický, P. (2017). Current development trends of media literacy in European Union countries. Communication Today, 8(1), 52. 
Previšić, V. (2005). Curriculum of modern education and school: methodology and structure. Pedagogijska istraživanja, 2(2), 165-166.

Sučević, V., Sakač, M., \& Bulatović, A. (2013). Kurikulum u funkciji kvalitetnog osnovnog obrazovanja - otvaranje prostora za autonomiju škola. Metodički obzori, 8(2013)1 (17), 15-28. DOI: https://doi.org/10.32728/mo.08.1.2013.01

Svalina, V., Bistrović, K., \& Peko, A. (2016). Izvannastavne glazbene aktivnosti u prva četiri razreda osnovne općeobrazovne škole. Napredak, 157(1-2), 71-89.

Syvertsen, T., Enli, G., Mjøs, O., \& Moe, H. (2014). Media Use. In The Media Welfare State: Nordic Media in the Digital Era (pp.24-46). ANN ARBOR: University of Michigan Press.

Vrkić Dimić, J. (2014). Suvremeni oblici pismenosti. Školski vjesnik, 63(3), 381-394.

Wahyuningsih, Y., Roesminingsih, E., \& Setyowati, S. (2018). Media Literacy in Extracurricular Activities of Journalism to Strengthen Civic Education. In $2^{\text {nd }}$ International Conference on Education Innovation (ICEI 2018), Advances in Social Science, Education and Humanities Research (pp.6-8). Atlantis Press.

Zgrabljić Rotar, N. (2005). Mediji - medijska pismenost, medijski sadržaji i medijski utjecaji. In N. Zgrabljić Rotar (Ed.), Medijska pismenost i civilno društvo (pp.9-43). Sarajevo: Mediacentar.

Zgrabljić Rotar, N. (2017). Novi mediji digitalnog doba. In Lj. Josić (Ed.), Informacijska tehnologija i mediji (pp.57-67). Zagreb: Hrvatski studiji Sveučilišta u Zagrebu.

Zhang, L., Zhang, H., \& Wang, K. (2020). Media literacy education and curriculum integration: A literature review. International Journal of Contemporary Education, 3(1), 55-64. 